\title{
Vasopressin atrial coronary constriction in humans: The unknown clinical significance of a laboratory finding
}

Juan A. Crestanello, MD

From the Department of Cardiovascular Surgery, Mayo Clinic, Rochester, Minn

Disclosures: Author has nothing to disclose with regard to commercial support.

Received for publication May 29, 2018; revisions received May 29, 2018; accepted for publication May 31, 2018; available ahead of print July 26, 2018.

Address for reprints: Juan A. Crestanello, MD, Department of Cardiovascular Surgery, Mayo Clinic, 200 First St SW, Rochester, MN 55905 (E-mail: crestanello.juan@mayo.edu).

J Thorac Cardiovasc Surg 2018;156:2108-9

$0022-5223 / \$ 36.00$

Copyright (C) 2018 by The American Association for Thoracic Surgery

https://doi.org/10.1016/j.jtcvs.2018.05.118

Vasodilatory shock occurs in $5 \%$ to $25 \%$ of patients after cardiac surgery and results in poor outcomes. ${ }^{1}$ It is treated with vasopressor that leads to vasoconstriction of the splanchnic and skeletal circulation, resulting in end-organ hypoperfusion. $^{2}$ Although catecholamine vasopressor therapy, its duration, and number of vasopressors used are associated with an increased risk of adverse cardiac and noncardiac events, vasopressin appears to have a more effective and safer profile in the treatment of vasodilatory shock after cardiac surgery. ${ }^{1,2}$ Vasopressin, a naturally occurring peptide, produces vasoconstriction by activating V1a receptor, blocking the opening of potassium adenosine triphosphate channels in vascular smooth muscle, and reducing nitric oxide production. ${ }^{3,4}$ Vasopressin depletion and decreased circulating levels of vasopressin are fundamental mechanisms responsible for vasodilatory shock after cardiac surgery. ${ }^{3,5,6}$ As such, vasopressin is commonly used to treat and prevent vasodilatory shock after cardiac surgery. In a prospective randomized controlled trial, Hajjar and colleagues ${ }^{1}$ showed that the use of vasopressin after cardiac surgery is associated with a reduction in 30-day mortality, postoperative renal failure, and postoperative atrial fibrillation compared with norepinephrine. Other investigators previously demonstrated that vasopressin is effective in treating vasodilatory shock after cardiac surgery, sepsis, and other vasodilatory conditions, decreasing catecholamine use with no increase in adverse events. ${ }^{7-9}$

Low ejection fraction, prolonged cardiopulmonary bypass (CPB), left ventricular assist device insertion, and preoperative use of angiotensin-converting enzyme inhibitors and beta-blockers are predictors of vasodilatory shock after cardiac surgery. ${ }^{3,6}$ Despite the profound microvascular dysfunction seen in diabetes, diabetes has not been identified clinically as a risk factor for vasoplegia. However, diabetes is associated with poor outcomes after cardiac surgery. Some of those adverse outcomes can be explained by the microvascular and macrovascular dysfunction seen in diabetic patients, which are exacerbated by CPB. ${ }^{10}$

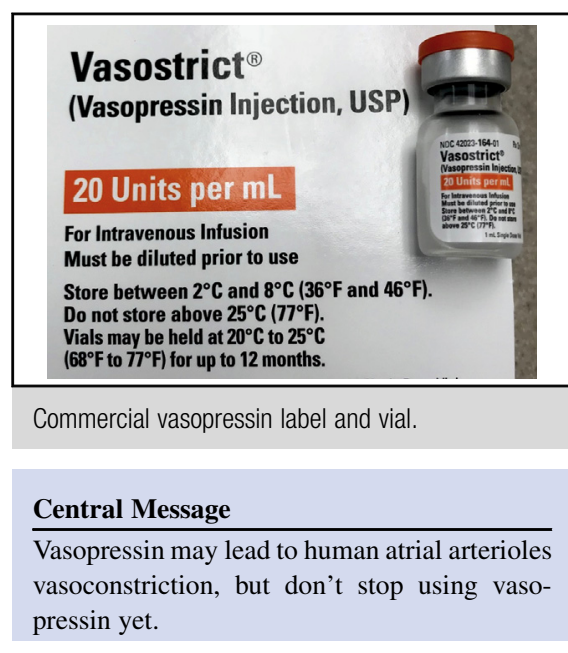

See Article page 2098.

In the current issue of the Journal, Sellke and colleagues ${ }^{11}$ explore the in vitro response of human atrial arterioles to vasopressin obtained before and after $\mathrm{CPB}$ in patients with poorly controlled diabetes and in nondiabetic controls. ${ }^{11}$ The in vitro vasoconstrictor response to vasopressin was increased in both diabetic and nondiabetic patients after CPB. The vasoconstrictor response was further amplified in diabetic patients, mediated by an increased expression of the vasopressin V1 receptor in vascular smooth muscle. ${ }^{11}$ This study adds to the seminal contributions on the topic of vascular reactivity in diabetic patients by the authors. The authors previously demonstrated that the contractile responses of skeletal muscle arterioles to phenylephrine and vasopressin were decreased after CPB in humans, while mesenteric vessels showed an increased response to norepinephrine and vasoconstriction with vasopressin remained unchanged. ${ }^{12,13}$ Khan and colleagues ${ }^{13}$ suggested that the use of vasopressin as a vasopressor after CPB may reduce the risk of mesenteric ischemia. The current study suggests that vasopressin use after CPB in patients with poorly controlled diabetes and in nondiabetic patients, but to a lesser degree, may be associated with atrial microvascular vasoconstriction and cardiac ischemia. The clinical significance of these findings is unknown, but if the effect of vasopressin is demonstrated in ventricular arterioles, it would raise more concern for adverse clinical implications. However, before changing your selection of vasopressors for the management of patients after cardiac surgery, a few cautionary points should be made. 
1. This was a small study that examined only atrial tissue arterioles, with no ventricular arterioles examined.

2. Other vasoconstrictors different than vasopressin were not evaluated. As such, it is possible that catecholamine vasopressor may have a similar or worse effect than vasopressin on atrial arterioles.

3. The increased response to vasopressin was not correlated with adverse outcomes in the present study.

4. Vasopressin has been extensively used in diabetic patients after cardiac surgery.

5. Diabetes has not been identified as a risk factor for adverse outcomes in the trials that examined the use of vasoconstrictors after vasodilatory shock.

6. Additional studies are necessary to confirm these findings and to elucidate their clinical implications.

\section{References}

1. Hajjar LA, Vincent JL, Barbosa Gomes Galas FR, Rhodes A, Landoni G, Osawa EA, et al. Vasopressin versus norepinephrine in patients with vasoplegic shock after cardiac surgery: the VANCS randomized controlled trial. Anesthesiology. 2017; 126:85-93.

2. Schmittinger CA, Torgersen C, Luckner G, Schröder DC, Lorenz I, Dünser MW. Adverse cardiac events during catecholamine vasopressor therapy: a prospective observational study. Intensive Care Med. 2012;38:950-8.

3. Shaefi S, Mittel A, Klick J, Evans A, Ivascu NS, Gutsche J, et al. Vasoplegia after cardiovascular procedures-pathophysiology and targeted therapy. J Cardiothorac Vasc Anesth. 2018;32:1013-22.
4. Russell JA. Vasopressin, norepinephrine, and vasodilatory shock after cardiac surgery: another "VASST" difference? Anesthesiology. 2017; $126: 9-11$.

5. Omar S, Zedan A, Nugent K. Cardiac vasoplegia syndrome: pathophysiology, risk factors and treatment. Am J Med Sci. 2015;349:80-8.

6. Argenziano M, Chen JM, Choudhri AF, Cullinane S, Garfein E, Weinberg AD, et al. Management of vasodilatory shock after cardiac surgery: identification of predisposing factors and use of a novel pressor agent. J Thorac Cardiovasc Surg. 1998;116:973-80.

7. Argenziano M, Choudhri AF, Oz MC, Rose EA, Smith CR, Landry DW. A prospective randomized trial of arginine vasopressin in the treatment of vasodilatory shock after left ventricular assist device placement. Circulation. 1997;96(9 Suppl):II286-90.

8. Dünser MW, Mayr AJ, Ulmer H, Knotzer H, Sumann G, Pajk W, et al. Arginine vasopressin in advanced vasodilatory shock: a prospective, randomized, controlled study. Circulation. 2003;107:2313-9.

9. Russell JA, Walley KR, Singer J, Gordon AC, Hébert PC, Cooper DJ, et al; VASST Investigators. Vasopressin versus norepinephrine infusion in patients with septic shock. N Engl J Med. 2008:358:877-87.

10. Feng J, Sellke F. Microvascular dysfunction in patients with diabetes after cardioplegic arrest and cardiopulmonary bypass. Curr Opin Cardiol. 2016; 31:618-24.

11. Sellke N, Kuczmarski A, Lawandy I, Cole VL, Ehsan A, Singh AK, et al Enhanced coronary arteriolar contraction to vasopressin in patients with diabetes after cardiac surgery. J Thorac Cardiovasc Surg. 2018;156:2098-107.

12. Khan TA, Bianchi C, Araujo EG, Ruel M, Voisine P, Li J, et al. Cardiopulmonary bypass reduces peripheral microvascular contractile function by inhibition of mitogen-activated protein kinase activity. Surgery. 2003;134: 247-54.

13. Khan TA, Bianchi C, Ruel M, Feng J, Sellke FW. Differential effects on the mesenteric microcirculatory response to vasopressin and phenylephrine after cardiopulmonary bypass. J Thorac Cardiovasc Surg. 2007; 133:682-8. 